\title{
EFISIENSI BIOFILTER AEROB MENGGUNAKAN MEDIA BOTOL SUSU FERMENTASI DALAM MENURUNKAN KADAR COD EFFLUENT BIODIGESTER INDUSTRI TAHU KECAMATAN CILONGOK
}

\author{
Tria Rafika Hidayah ${ }^{1)}$, Budi Triyantoro ${ }^{2)}$, Sugeng Abdullah 3) \\ Poltekkes Kemenkes Semarang, Poltekkes Kemenkes Semarang, Poltekkes Kemenkes Semarang
}

\begin{abstract}
ABSTRAK
Biodigester unit 3 merupakan salah satu instalasi pengolahan air limbah tahu menjadi biogas di Desa Kalisari Kecamatan Cilongok. Air limbah yang telah diolah menjadi biogas akan menghasilkan air buangan (effluent), kemudian dibuang ke irigasi yang disalurkan ke sungai Krukut. Sungai tersebut sering dimanfaatkan warga untuk mandi dan mencuci pakaian. Effluent biodigester unit 3 masih memiliki kadar COD sebesar $1.048 \mathrm{mg} / \mathrm{l}$, sehingga diperlukan proses pengolahan lanjutan dengan proses aerob menggunakan biofilter media botol susu fermentasi.Tujuan penelitian ini adalah mengetahui efisiensi biofilter aerob menggunakan media botol susu fermentasi sebagai pengolahan lanjut dalam menurunkan kadar COD effluent biodigester unit 3 .

Penelitian ini menggunakan jenis penelitian Pre experiment dengan metode pre and post test. Hasil rerata suhu influent biofilter aerob yaitu $26,16^{\circ} \mathrm{C}$, hasil rerata suhu effluent biofilter yaitu $28,16^{\circ} \mathrm{C}$. Hasil rerata $\mathrm{pH}$ influent biofilter yaitu 6,53 , kemudian rerata $\mathrm{pH}$ effluent biofilter yaitu 7,5. Hasil rerata pemeriksaan COD influent biofilter aerob yaitu 97,667 mg/l, hasil rerata pemeriksaan COD effluent biofilter yaitu 30,667 mg/l. Kadar COD effluent biofilter aerob tidak melebihi kadar maksimal pada baku mutu Peraturan Daerah Provinsi Jawa Tengah Nomor 5 Tahun 2012, sehingga kadar COD effluent biofilter telah memenuhi syarat. Rerata efisiensi penurunan kadar COD pada biofilter aerob yaitu $66,846 \%$. Hasil analisis statistik kadar COD diperoleh nilai signifikan $(P$ value $)$ sebesar 0,07 yang menunjukkan bahwa sig $(P$ value $)>\alpha$ $(0,05)$, sehingga tidak ada perbedaan yang signifikan antara hasil pemeriksaan COD influent dan effluent biofilter aerob. Kesimpulan dari penelitian ini adalah biofilter aerob dengan media botol susu fermentasi belum efisien dalam menurunkan kadar COD dengan stabil. Saran pada penelitian ini adalah perlu dilakukan penelitian lanjut dengan menambah luas spesifik media biofilter, perlu dilakukan proses aklimatisasi, perlu dilakukan penelitian lanjut dengan pemeriksaan parameter kinerja biofilter aerob.
\end{abstract}

Kata Kunci : Biofilter aerob; media botol susu fermentasi; Kadar COD

\begin{abstract}
Unit 3 biodigester is one of wastewater-to-biogas treatment plant in Desa Kalisari, Kecamatan Cilongok. The treatment of wastewater to biogas produces effluents, which will then channeled to Krukut River, which is usually used by surrounding inhabitants for bathing and washing clothes. Effluents produced still had COD level of $1.408 \mathrm{mg} / \mathrm{l}$, indicating that an advanced treatment is needed, by using aerob process with fermented milk bottle as media. The research is aimed to understanding the efficiency of aerob biofilter made from fermented milk bottle media as an advanced wastewater treatment in decreasing the COD level of unit 3 biodigester effluents.

The research used pre-experiment research type with pre- and post-test design method, The research result shows that average temperature of the aerob biofilter influent was $26,16^{\circ} \mathrm{C}$, while the average temperature of the aerob biofilter effluent was $28,16^{\circ} \mathrm{C}$. It also shows that the influent's average $\mathrm{pH}$ of was 6,53, while the effluent's average $\mathrm{pH}$ was 7,5. It demonstrates further that the influent's average COD level was $97,667 \mathrm{mg} / \mathrm{l}$, while the effluent's average COD level was 30,667 mg/l. The effluent's COD level did not exceed maximum level of environmental quality standards as stated in Regional Regulation of Central Java Province No. 5 of 2012, thus making it acceptable. The average efficiency of COD level decrease in the aerob biofilter was $66,846 \%$. Based on the COD level statistical analysis result, p-value of 0,07 was obtained,

\footnotetext{
1) email: triahidayah39@yahoo.com

$\left.{ }^{2}\right)$ email: buditri1309@gmail.com

${ }^{3}$ ) email: sugengzend@yahoo.com
} 
showing that sig $(P$ value $)>\alpha(0,05)$, and therefore no significant difference in COD level examination result between the influent and the effluent was found. The researcher concluded that aerob biofilter made from fermented milk media is not yet efficient in gradually decreasing the COD level. It is recommended that a further research is needed by adding specific area of biofilter media. Acclimatization process, Further research by examining parameter of aerob biofilter performance.

Keywords: Aerob biofilter; fermented milk bottle media; COD level

\section{Pendahuluan}

Menurut H.L. Blum (dalam Indonesian Public Health, 2015), derajat kesehatan dipengaruhi oleh beberapa faktor, yaitu: lingkungan, perilaku, pelayanan medis dan keturunan. Faktor yang mempunyai pengaruh terhadap kesehatan adalah keadaan lingkungan yang tidak memenuhi syarat kesehatan dan perilaku masyarakat yang merugikan, baik masyarakat di pedesaan maupun perkotaan yang disebabkan oleh kurangnya pengetahuan dan kemampuan masyarakat bidang kesehatan, ekonomi maupun teknologi.

Masalah lingkungan di daerah pedesaan maupun perkotaan dapat terjadi, karena pengolahan air limbah yang tidak ditangani dengan semestinya. Air limbah merupakan bahan buangan yang timbul karena adanya kehidupan manusia. Kedudukan manusia sebagai makhluk individu maupun makhluk yang dominan dalam menentukan terjadinya perubahan di berbagai aspek kehidupan dan lingkungan dituntut untuk memenuhi kebutuhan hidupnya, salah satunya adalah makanan. Untuk memenuhi kebutuhan makanan manusia, memerlukan berbagai kegiatan manusia, seperti industri pangan yang memerlukan air. Menurut Soeparman dan Suparmin (2001), penggunaan air akan mengakibatkan industri memiliki bahan buangan, yaitu air limbah pada industri pangan.

Industri pangan yang saat ini masih menghasilkan air limbah dan dimungkinkan dapat menyebabkan pencemaran pada lingkungan adalah industri tahu. Air banyak digunakan sebagai pencuci kedelai dan perendam kedelai sehingga air bekas cucian dan rendaman kedelai tidak digunakan lagi, kemudian menjadi air limbah. Oleh karena itu, air limbah yang dihasilkan dalam produksi tahu cukup besar. Kadar pencemar pada air limbah industri tahu yang melebihi standar akan menyebabkan gangguan yang cukup serius terutama untuk perairan di sekitar industri tahu (Heru Dwi Wahjono, 2002, h. 152).

Air limbah tahu sebagian besar terdiri dari bahan organik berupa karbohidrat, protein, lemak, dan bahan penyusun lainnya. Kandungan bahan organik dalam limbah tersebut dapat menjadi sumber makanan untuk pertumbuhan mikroba. Mikroorganisme akan tumbuh dengan cepat apabila memiliki pasokan makanan yang berlimpah dan mereduksi Oksigen yang terlarut dalam air. Secara normal, air mengandung kira-kira 8 ppm Oksigen terlarut. Standar minimum Oksigen terlarut untuk kehidupan ikan adalah 5 ppm. Apabila Oksigen terlarut kurang dari 5 ppm, hal tersebut akan menyebabkan kematian ikan dan biota perairan lainnya (Betty Sri Laksmi Jenie, 2007).

Peraturan Daerah Provinsi Jateng Nomor 5 Tahun 2012 menyebutkan bahwa air limbah industri tahu memiliki ketentuan jumlah kadar maksimal dari beberapa parameter. Parameterparameter tersebut yaitu: $\mathrm{pH}$, Total Suspended Solid (TSS), Chemycal Oxigen Demand (COD) dan Biologycal Oxygen Demand (BOD). Kadar maksimal $\mathrm{pH}$ yaitu antara 6-9, kadar TSS maksimal yaitu $100 \mathrm{mg} / \mathrm{l}$, kadar maksimal COD yaitu $275 \mathrm{mg} / \mathrm{l}$, BOD yaitu $150 \mathrm{mg} / \mathrm{l}$.

Menurut Hery (Ayu Tika, 2015), air limbah tahu mempunyai tingkat pencemaran yang tinggi, karena kadar BOD sekitar 6.000$8.000 \mathrm{mg} / \mathrm{l}$ dan COD sekitar 8.000-11.400 $\mathrm{mg} / \mathrm{l}$. Sebagai contoh air limbah industri tahu tempe di Semanan, Jakarta Barat, kadar BOD 5 mencapai 1.324 mg/l, COD $6.698 \mathrm{mg} / \mathrm{l}$, Nitrat $1,76 \mathrm{mg} / \mathrm{l}$ dan Nitrit $0,17 \mathrm{mg} / \mathrm{l}$. Jika ditinjau dari Kep-03/MENKLH/11/1991 tentang baku mutu air limbah, maka industri tahu memerlukan pengolahan air limbah. Hasil pengukuran air limbah tahu lainnya di DKI Jakarta menunjukkan pencemaran yang cukup tinggi. Nilai BOD $_{5}$ air limbah tahu berkisar 910$12.100 \mathrm{mg} / \mathrm{l}$, sedangkan nilai COD berkisar antara 1.102-15.055 mg/l (Heru Dwi Wahjono, 2002, h. 158).

Kadar COD pada limbah yang melebihi kadar maksimal baku mutu, menunjukkan tingginya bahan anorganik dan organik yang terdapat pada air limbah. Senyawa tersebut memiliki sifat akumulatif dan sulit untuk terurai. Jika manusia sering terpapar air yang tercemar kadar COD, maka senyawa pencemar akan terakumulasi pada tubuh manusia, sehingga kesehatan manusia akan terganggu (Arif Sumantri, 2010). Konsentrasi COD yang tinggi menyebabkan kandungan Oksigen terlarut di dalam air menjadi rendah, bahkan habis sama sekali. Akibatnya, Oksigen sebagai sumber kehidupan bagi biota air tidak dapat 
terpenuhi, sehingga biota air tersebut manjadi mati. (Monahan dalam Ridho Hasan, 2016).

Tingginya kadar COD pada air limbah industri tahu yang berdampak pada kesehatan manusia dan lingkungan perlu ditangani dengan tujuan dampak dari pencemaran tersebut tidak terjadi. Penanganan dapat dilakukan dengan melakukan pengolahan air limbah baik secara anaerob maupun aerob. Pengolahan anaerob dapat dilakukan dengan reaktor, seperti reaktor biodigester. Pengolahan aerob dapat dilakukan dengan lumpur aktif atau pengolahan dengan proses film mikrobiologis seperti biofilter (Heru Dwi Wahjono, 2002).

Industri tahu di Desa Kalisari telah dilakukan pengolahan secara anaerob, yaitu pengolahan air limbah menjadi biogas menggunakan biodigester. Pengolahan air limbah industri tahu menjadi biogas masih menghasilkan effluent pada biodigester yang digunakan. Berdasarkan hasil penelitian Laboratorium Kesehatan Masyarakat Kabupaten Banyumas, effluent pada biodigester unit 3 masih memiliki kadar COD yaitu $1.048 \mathrm{mg} / 1$. Effulent tersebut masih belum memenuhi baku mutu air limbah yang telah ditetapkan pada Peraturan Daerah Provinsi Jawa Tengah Nomor 05 Tahun 2012. Kadar maksimal COD pada air limbah tahu yang telah ditentukan adalah $275 \mathrm{mg} / \mathrm{l}$. Hal ini diduga karena media filter yang digunakan untuk tempat melekatnya bakteri terbuat dari kayu yang tersusun. Effluent biodigester unit 3 pada industri tahu Desa Kalisari Kecamatan Cilongok masih memiliki kadar COD yang melebihi baku mutu, sehingga diperlukan pengolahan lanjut pada effluent biodigester. Pengolahan lanjut pada reaktor biodigester ini yaitu pengolahan secara aerob menggunakan biofilter dengan media plastik botol susu fermentasi.

Tujuan penelitian ini adalah mengetahui efisiensi biofilter aerob menggunakan media botol susu fermentasi sebagai pengolahan lanjut dalam menurunkan kadar COD effluent biodigester unit 3 .

\section{Bahan dan Metode}

Penelitian ini menggunakan jenis penelitian Experiment Design dengan bentuk Pra Experiment yang memiliki rancangan one group pre-test and post-test design. Penelitian ini dilaksanakan di biodigester Industri tahu khususnya pada biodigester unit 3 di Desa Kalisari Kecamatan Cilongok Kabupaten Banyumas, Laboratorium Kesehatan Masyarakat Kabupaten Banyumas dan Laboratorium Kesehatan Kabupaten Purbalingga.
Replikasi pada penelelitian ini dilakukan sebanyak 3 kali yang menggunakan 3 model biofilter aerob. Sampel yang diambil dalam penelitian adalah effluent biodigester unit 3 industri tahu (merupakan influent biofilter aerob) sebanyak 3 sampel dan effluent biofilter aerob sebanyak 3 sampel. Jumlah sampel setiap perlakuan sesuai dengan banyaknya replikasi. Setiap sebelum dan sesudah perlakuan, terlebih dahulu air limbah diambil sebagai sampel untuk pemeriksaan. Instrument yang digunakan pada penelitian ini yaitu: kuesioner, alat untuk mengukur $\mathrm{pH}$ meter, stopwatch, thermometer, botol sampel untuk pemeriksaan kadar COD air limbah di laboratorium, dan model dari biofilter aerob yang sudah dilakukan proses seeding.

Analisis peneltian ini yaitu Analisis univariat untuk menganalisis data hasil penelitian ditabulasi selanjutnya dianalisis dengan menghitung nilai mean dan efisiensi penurunan COD setelah dilakukan pengolahan dengan rancangan biofilter aerob, kemudian analisis bivariat untuk data hasil penelitian ditabulasi selanjutnya dianalisis menggunakan program SPSS dengan uji statistik Paired $t$ Test.

\section{Hasil dan Pembahasan}

\section{A. Data Umum}

1) Gambaran Umum Biodigester Unit 3 Biodigester unit 3 merupakan salah satu instalasi pengolahan air limbah tahu yang terletak di RT 04 RW 02 Desa Kalisari Kecamatan Cilongok. Biodigester ini dibangun pada tahun 2013 dengan luas lahan $125 \mathrm{~m}^{2}$. Biodigester unit 3 merupakan biodigester terbesar kedua setelah biodigester unit 4. Badan Pengkajian dan Penerapan Teknologi (BPPT) melakukan pembangunan biodigester unit 3 setelah proyek biodigester unit 1 sukses dioperasikan, sehingga mengurangi pencemaran yang disebabkan oleh air limbah tahu. Biodigester ini mengolah air limbah tahu yang dihasilkan dari kelompok UKM (Usaha Kecil Menengah) warga desa Kalisari sebanyak 43 UKM.

Jumlah kedelai yang diolah menjadi tahu dari kelompok UKM wilayah 3 sebanyak $2.150 \mathrm{~kg} / \mathrm{hari}$. Tangki reaktor biodigester unit 3 yang mengolah air limbah tahu menjadi biogas memiliki 1 tangki. Kapasitas maksimal gas yang dihasilkan tangki reaktor yaitu $15.050 \mathrm{~kg} / \mathrm{hari}$. Gas tersebut kemudian disalurkan ke rumah warga sebanyak 67 rumah. Masing- 
masing rumah akan menerima gas sebanyak $224 \mathrm{~kg} / \mathrm{hari} / \mathrm{rumah}$. Warga yang menerima gas membayar dana swadaya sebesar Rp 15.000/bulan.

Air limbah yang dihasilkan dari produksi tahu pada UKM dialirkan ke instalasi biodigester dengan sistem gravitasi, kemudian air limbah akan ditampung pada bak penangkap. Kapasitas maksimal air limbah tahu yang diolah pada biodigester unit 3 yaitu 10.000 Liter. Sistem pengaliran yang digunakan untuk pengoperasian pada biodigester ini adalah sistem pompa. Pemompaan air limbah tahu dari bak penangkap ke reaktor dilakukan setiap pagi hari pukul 05.30 WIB dan sore hari pada pukul 17.00 WIB. Pemompaan dilakukan selama 15 menit dengan debit sebesar 120 liter/menit. Air limbah yang telah diolah menjadi biogas akan menghasilkan air buangan (effluent), kemudian dibuang ke sungai.

Berdasarkan wawancara yang telah dilaksanakan dengan petugas seksi perawatan, biodigester unit 3 sering mengalami kebocoran pada reaktor pengolah biogas. Kebocoran reaktor akan mengakibatkan air limbah tidak terolah menjadi biogas dengan baik. Kebocoran ditandai dengan adanya retakan pada reaktor digester dan tidak munculnya gas pada tabung uji. Tabung uji yang digunakan diisi air, kemudian selang penyalur gas dimasukkan kedalam tabung tersebut. Apabila gelembung tidak muncul, hal tersebut menandakan adanya masalah yang timbul pada reaktor. Penanganan masalah kebocoran pada reaktor dapat dilakukan dengan cara pengecatan ulang dinding luar bagian reaktor yang bocor. Seksi perawatan harus memantau tabung uji secara rutin dan mengetahui adanya retakan pada reaktor agar perbaikan segera dilakukan, sehingga udara tidak akan masuk kedalam reaktor. Jika kebocoran terjadi tanpa diketahui seksi perawatan, udara akan masuk kedalam reaktor sehingga mengganggu proses pembentukan biogas pada reaktor. Menurut Heru Dwi Wahjono (2002), pengolahan air limbah dengan cara anaerob merupakan pengolahan yang memanfaatkan bakteri anaerob yang bekerja tanpa membutuhkan Oksigen. Oksigen akan menyebabkan pertumbuhan bakteri anaerob menjadi terhambat. Jika pengolahan anaerob tercampur dengan Oksigen, pembentukan gas yang dihasilkan akan tidak terjadi secara sempurna.

Berdasarkan hasil pemeriksaan Laboratorium Kesehatan Masyarakat Kabupaten Banyumas, effluent biodigester unit 3 masih memiliki kadar COD sebesar $1.048 \mathrm{mg} / \mathrm{l}$. Effluent tersebut masih belum memenuhi baku mutu air limbah yang telah ditetapkan pada Peraturan Daerah Provinsi Jawa Tengah Nomor 5 Tahun 2012. Kadar maksimal COD pada air limbah tahu yang telah ditentukan adalah $275 \mathrm{mg} / \mathrm{l}$, sehingga kadar COD effluent melebihi kadar maksimal. Effluent dari biodigester unit 3 langsung dibuang ke iringasi yang disalurkan ke sungai Krukut. Berdasarkan hasil pengamatan sepintas peneliti, sungai tersebut sering dimanfaatkan warga untuk mandi dan mencuci pakaian. Jika warga memanfaatkan air sungai yang telah tercemar untuk memenuhi kebutuhannya, maka akan terjadi gangguan kesehatan. Menurut Arif Sumantri (2010), kadar COD pada limbah yang melebihi kadar maksimal baku mutu, menunjukkan tingginya bahan anorganik dan organik yang terdapat pada air limbah. Senyawa tersebut memiliki sifat akumulatif dan sulit untuk terurai. Jika manusia sering terpapar air yang tercemar kadar COD, maka senyawa pencemar akan terakumulasi pada tubuh manusia, sehingga kesehatan manusia akan terganggu. Peneliti berencana melakukan pengolahan lanjut pada effluent biodigester untuk meminimalisir kadar COD, sehingga permasalahan yang ditimbulkan oleh effluent dapat teratasi.

2) Struktur Organisasi Pengelola Biodigester Unit 3 Desa Kalisari

Penanggung jawab seluruh instalasi pengolahan air limbah tahu di Desa Kalisari Kecamatan Cilongok adalah Bapak Suwanto selaku Kepala Dusun 1 Desa Kalisari Kecamatan Cilongok. Ketua pengelola biodigester unit 3 adalah Bapak Rodin. Sekretaris pengelola biodigester unit 3 adalah Bapak Wikarso. Bendahara biodigester unit 3 yaitu Bapak Puji Wikarto. Seksi perawatan biodigester unit 3 dikoordinir oleh Bapak Kislam, kemudian beranggotakan Bapak Riyono dan Kuswanto. Berdasarkan hasil 
wawancara yang telah dilakukan dengan petugas pengelola, BPPT menyarankan bahwa pengelolaan biodigester diperlukan kepengurusan dengan jumlah anggota 6-8 orang. Tenaga pengelola biodigester yang diperlukan adalah tenaga swadaya yang berasal dari kelompok warga yang menerima biogas.

Masing-masing tenaga pengelola memiliki tugas dan kewajiban yang harus dilaksanakan secara rutin. Ketua bertugas untuk mengawasi dan melaporkan kepada Perangkat Desa tentang laporan keuangan dan masalah yang terjadi pada pengelolaan biodigester. Sekretaris bertugas untuk mencatat hasil pertemuan rutin dan membuat proposal untuk pengadaan inventaris kelengkapan biodigester. Bendahara bertugas untuk mengkoordinir dana yang masuk dan keluar untuk pengadaan inventaris serta pembelian alat-alat untuk perbaikan biodigester. Seksi perawatan bertugas untuk mengontrol dan merawat seluruh komponen biodigester. Kepengurusan biodigester unit 3 hingga saat ini masih terbentuk dengan baik. Pertemuan setiap pengurus biodigester diadakan bulan dengan agenda evaluasi kondisi biodigester.

Tenaga pengelola telah memperoleh pelatihan yang diadakan oleh Tim Teknis dari BPPT selama 3 hari. Materi yang diberikan kepada petugas pengelola yaitu cara mengelola, mengawasi, mengontrol, dan memecahkan masalah apabila terjadi masalah pada biodigester. Materi lapangan yang diberikan yaitu cara pengoperasian dan teknik untuk memecahkan masalah yang mungkin terjadi pada biodigester. Saat ini, petugas pengelola sudah menerapkan materi yang telah diberikan oleh BPPT. Petugas pengelola telah menangani berbagai permasalahan pada biodigester dengan baik, seperti kebocoran pada reaktor dan penyumbatan pompa.

3) Sistem Pengolahan Air Limbah pada Biodigester Unit 3 Desa Kalisari

Air limbah pada proses pembuatan tahu dihasilkan dari proses pencucian kedelai, perendaman kedelai dan pemadatan tahu. Menurut Heru Dwi Wahjono (2002), Air limbah tersebut mengandung berbagai bahan organik yaitu protein, lemak, asam cuka dan bahan penggumpal tahu.
Air limbah tahu disaring pada bak penyaring dari sampah dan padatan yang akan menghambat proses pengolahan air limbah tahu. Bak penyaring terdapat di setiap kelompok UKM. Penyaring yang digunakan terbuat dari besi. Menurut Heru Dwi Wahjono, (2002), air limbah tahu pada umumnya bersifat asam. Hal tersebut menunjukan bahwa air limbah tahu menyebabkan penyaring menjadi berkarat, sehingga penyaring tersebut perlu diganti. Air limbah yang telah dilakukan penyaringan kemudian memasuki jaringan induk biodigester.

Air limbah yang memasuki jaringan induk biodigester kemudian ditampung pada bak penangkap. Bak penangkap merupakan tempat untuk menampung air limbah yang masuk kedalam biodigester dari berbagai sumber rumah UKM. Bak penangkap akan mendinginkan air limbah tahu yang masih memiliki suhu yang tinggi. Menurut Heru Dwi Wahjono (2002), suhu air limbah tahu pada umumnya yaitu $40^{\circ} \mathrm{C}-46^{\circ} \mathrm{C}$. Bak penangkap juga berfungsi untuk menghomogenkan kandungan zat dan $\mathrm{pH}$ air limbah tahu yang berasal dari berbagai sumber produksi. Setelah karakteristik air limbah telah homogen, air limbah akan disalurkan ke reaktor digester menggunakan pompa.

Reaktor digester merupakan bangunan kedap udara yang digunakan sebagai tempat pembentukan biogas. Reaktor ini terbuat dari bahan fiberglass. Reaktor digester yang digunakan merupakan jenis reaktor fix dome. Menurut Arie Herlambangan (2002), tipe reaktor jenis dome cocok digunakan untuk mengolah air limbah dengan volume besar karena tahan terhadap tekanan tinggi. Reaktor digester dilengkapi dengan katup pengaman tekanan sebagai pengatur tekanan gas dalam digester. Reaktor ini memiliki volume tetap sehingga produksi biogas akan meningkatkan tekanan dalam reaktor.

Biogas yang telah terbentuk, kemudian ditampung pada gas holder. Gas holder merupakan bangunan berbentuk tabung untuk menampung biogas hasil dari pengolahan air limbah tahu, kemudian gas tersebut didistribusikan ke rumah warga melalui jaringan pipa. Gas holder terbuat dari bahan fiberglass. Pada bagian bawah 
tangki ini diisi air bersih sebagai

penekan gas pada penampung gas.

\section{B. Data Khusus}

1) Kriteria desain biofilter aerob

Pengolahan effluent biodigester unit 3 dilakukan dengan cara pengoperasian biofilter aerob menggunakan media botol susu fermentasi. Proses pengolahan air limbah dengan proses biofilter aerob dilakukan dengan cara mengalirkan air

limbah ke dalam reaktor yang diisi dengan media penyangga untuk pengembangbiakan mikroorganisme dengan aerasi. Posisi media biofilter berada di bawah permukaan air (M. Solichin, 2012).

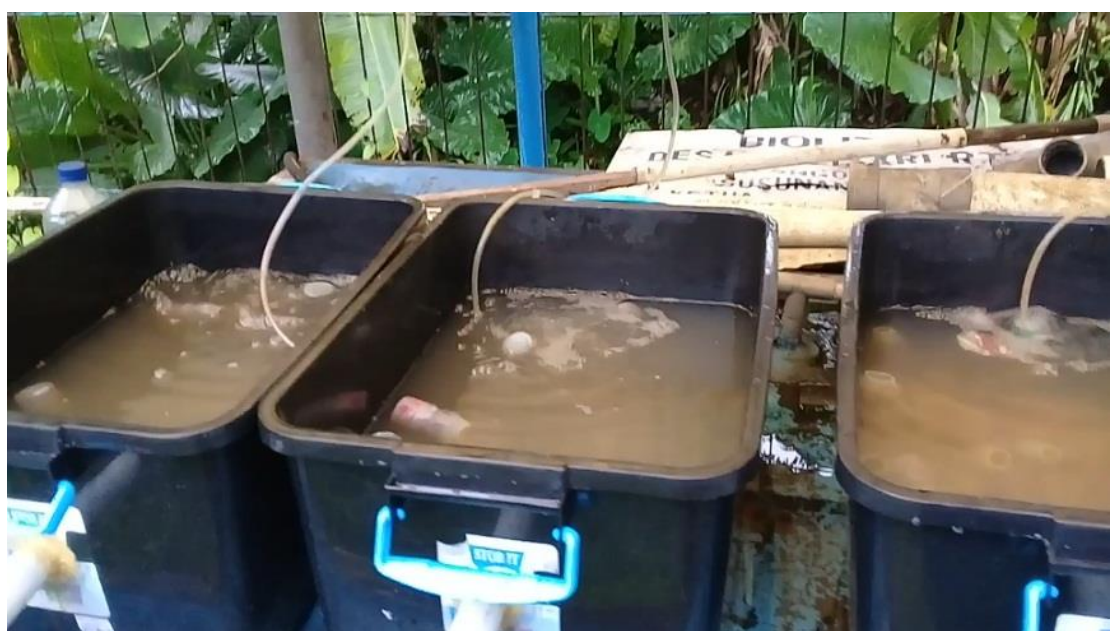

Gambar Model Biofilter Aerob menggunakan Media Botol Susu Fermentasi.

Tabel Kriteria Desain Biofilte Aerob

\begin{tabular}{|c|c|c|c|}
\hline No. & Komponen & Kriteria desain & Keterangan \\
\hline \multirow[t]{5}{*}{1.} & Kontainer reaktor & Bahan & Plastik LDPE \\
\hline & & Dimensi & $45 \mathrm{~cm} \times 29,5 \mathrm{~cm} \times 24,5 \mathrm{~cm}$ \\
\hline & & Volume & 20 liter \\
\hline & & Waktu tunggu & 24 jam \\
\hline & & Tipe pengolahan & Batch \\
\hline \multirow[t]{2}{*}{2.} & Media Biofilter & Bahan & Plastik PE \\
\hline & & Luas spesifik & $1.719,95$ liter $/ \mathrm{m}^{3}$ \\
\hline \multirow[t]{3}{*}{3.} & Aerator & Power & 5 watt \\
\hline & & Dimensi & $19,6 \mathrm{~cm} \times 14 \mathrm{~cm} \times 10,5 \mathrm{~cm}$ \\
\hline & & Aliran udara & 540 liter/jam \\
\hline \multirow[t]{2}{*}{4.} & Lubang penguras & Ukuran & 1,5 inch \\
\hline & & Panjang & $15 \mathrm{~cm}$ \\
\hline
\end{tabular}

Proses biofilter aerob memerlukan suplay udara yang dilakukan dengan cara aerasi. Model aerasi pada penelitian ini yaitu aerasi tengah. Menurut Direktorat Jenderal Bina Upaya Kesehatan (2011), penggunaan aerasi tengah pada biofilter aerob dapat menyerap Oksigen dalam jumlah yang besar. Media yang digunakan pada biofilter aerob terbuat dari bahan plastik PE dengan bentuk botol yang berlekuk-lekuk sehingga memiliki luas permukaan yang besar. Menurut Ikbal (2010), media biofilter terbuat dari bahan yang tidak mudah terurai dan tidak mudah membusuk dengan luas permukaan spesifik yang besar dapat melekatkan mikroorganisme dalam jumlah yang besar.

Mikroorganisme yang berperan pada pengolahan secara aerob yaitu bakteri Bacillus sp dan Acinetobacter sp. Menurut Biyatmoko (2012), bakteri Bacillus sp merupakan bakteri yang menempel pada media dan berperan dalam penguraian polutan organik pada air limbah. Acinetobacter sp merupakan bakteri yang dapat mereduksi nitrat pada kondisi aerob. 
2) Pengukuran Suhu

Tabel Hasil Pengukuran Suhu Influent dan Effluent Biofilter Aerob di Desa Kalisari Kecamatan Tanggal 7 Maret 2018

\begin{tabular}{cccc}
\hline \multirow{2}{*}{ No. } & \multirow{2}{*}{ Replikasi } & \multicolumn{2}{c}{$\begin{array}{c}\text { Hasil pengukuran } \\
\text { suhu }\left({ }^{\mathbf{O}} \mathbf{C}\right)\end{array}$} \\
\cline { 3 - 4 } & & Influent & Effluent \\
\hline 1. & 1 & 26,0 & 28,0 \\
2. & 2 & 26,0 & 28,0 \\
3. & 3 & 26,5 & 28,5 \\
\hline Rerata & & 26,16 & 28,16 \\
\hline
\end{tabular}

Hasil rerata suhu influent biofilter aerob yaitu $26,16^{\circ} \mathrm{C}$. Rerata suhu effluent biofilter aerob setelah dilakukan pengolahan selama 24 jam dengan replikasi penelitian sebanyak 3 kali yaitu $28,16^{\circ} \mathrm{C}$. Menurut Biyatmoko (2012), lapisan biofilm pada media penyangga terdiri dari beberapa jenis bakteri mesofilik. Bakteri mesofilik memiliki suhu minimum agar tetap hidup yaitu $15^{\circ} \mathrm{C}$, suhu optimum untuk pertumbuhan bakteri yaitu $25-37^{\circ} \mathrm{C}$, dan suhu maksimum agar tetap hidup yaitu $45-55^{\circ} \mathrm{C}$ (Sumarsih, 2003). Hasil rata-rata suhu influent dan effluent biofilter aerob menunjukkan suhu optimum untuk aktivitas mikroorganisme. Suhu pada effluent biofilter lebih tinggi dari influent biofilter.

Pengukuran suhu dilakukan pada pukul 17.00 WIB. Kondisi cuaca pada saat pengukuran suhu yaitu cerah berawan. Suhu udara pada saat pengolahan yaitu $27,5^{\circ} \mathrm{C}$. Hasil pengukuran tersebut menunjukkan bahwa suhu udara tidak jauh berbeda dengan influent dan effluent biofilter aerob, sehingga tidak mempengaruhi proses pengolahan pada biofilter aerob. Menurut Tommy Wijayanarko (2017), suhu pada air limbah mengalami kenaikan pada saat diolah menggunakan biofilter karena adanya faktor yang mempengaruhi, yaitu kondisi suhu lingkungan dan adanya aktivitas mikroorganisme. Mikroorganisme mengalami peningkatan metabolisme pada suhu optimum, sehingga suhu pada air limbah setelah dilakukan pengolahan mengalami peningkatan.
3) Pengukuran $\mathrm{pH}$

Tabel 4.2 Hasil Pengukuran pH Influent dan Effluent Biofilter Aerob di Desa Kalisari Kecamatan Tanggal 7 Maret 2018

\begin{tabular}{lccc}
\hline \multirow{2}{*}{ No. } & \multirow{2}{*}{ Replikasi } & \multicolumn{2}{c}{$\begin{array}{c}\text { Hasil } \\
\text { pengukuran } \mathbf{~ p H}\end{array}$} \\
\cline { 3 - 4 } & & Influent & Effluent \\
\hline 1. & 1 & 6,2 & 7,6 \\
2. & 2 & 6,6 & 7,7 \\
3. & 3 & 6,8 & 7,2 \\
\hline Rerata & 6,53 & 7,5 \\
\hline \multicolumn{2}{r}{ Hasil rerata } & pH influent biofilter
\end{tabular}

Hasil rerata $\mathrm{pH}$ influent biofilter aerob yaitu 6,53. Rerata $\mathrm{pH}$ effluent biofilter aerob setelah dilakukan pengolahan selama 24 jam dengan replikasi penelitian sebanyak 3 kali yaitu 7,5. Menurut Sumarsih (2003), Parameter $\mathrm{pH}$ merupakan faktor kunci bagi pertumbuhan mikroorganisme. Beberapa bakteri tidak dapat hidup pada $\mathrm{pH}$ diatas 9,5 dan dibawah 4,0. Secara umum, $\mathrm{pH}$ optimum bagi pertumbuhan mikro-organisme adalah 6,5-7,5. Bakteri mesofilik merupakan kelompok bakteri yang dapat hidup pada $\mathrm{pH}$ 5,58 ,0. Hasil rata-rata $\mathrm{pH}$ influent dan effluent biofilter aerob menunjukkan $\mathrm{pH}$ optimum untuk aktivitas mikroorganisme. $\mathrm{pH}$ pada effluent biofilter lebih tinggi dari influent biofilter.

Sisa-sisa senyawa kimia dari limbah tahu dan bahan pencemar pada effluent biodigester diolah menggunakan biofilter aerob. Menurut Heru Dwi Wahjono (2002), pengolahan lanjut secara aerob dapat meningkatkan proses penguraian senyawa organik dan bahan pencemar. Beberapa senyawa kimia yang tersisa seperti protein, lemak, asam cuka dan bahan penggumpal tahu yang bersifat asam akan diuraikan oleh mikroorganisme, sehingga air limbah dapat terolah secara optimal. Penguraian sisa senyawa kimia dari limbah tahu menyebabkan $\mathrm{pH}$ effluent lebih tinggi dari influent. 
4) Hasil Pemeriksaan COD

Tabel Hasil Pemeriksaan COD Influent dan Effluent Biofilter Aerob di Desa Kalisari Kecamatan Tanggal 7 Maret 2018

\begin{tabular}{ccccc}
\hline \multirow{2}{*}{ No. } & \multirow{2}{*}{ Replikasi } & \multicolumn{2}{c}{ Hasil pemeriksaan COD (mg/l) } & \multirow{2}{*}{ Efisiensi (\%) } \\
\cline { 3 - 4 } & & Influent & Effluent & \\
\hline 1. & 1 & 79 & 40 & 49,367 \\
2. & 2 & 110 & 5 & 95,454 \\
3. & 3 & 104 & 47 & 54,807 \\
\hline Rata-rata & & 97,667 & 30,667 & 66,846 \\
\hline
\end{tabular}

Hasil rerata kadar COD influent biofilter aerob yaitu $97,667 \mathrm{mg} / \mathrm{l}$. Rerata kadar COD effluent biofilter aerob setelah dilakukan pengolahan selama 24 jam dengan replikasi penelitian sebanyak 3 kali yaitu 30,667 mg/l. Kadar COD setelah dilakukan pengolahan mengalami penurunan. Menurut Direktoral Jenderal Bina Upaya Kesehatan (2011), polutan organik seperti COD yang ada di dalam air limbah akan terurai pada pengolahan air limbah secara aerob. Hasil penguraian polutan tersebut adalah gas Karbon Dioksida $\left(\mathrm{CO}_{2}\right)$ dan air $\left(\mathrm{H}_{2} \mathrm{O}\right)$. Mikroorganisme yang melekat pada media biofilter akan mendifusi COD ke dalam lapisan film biologis yang melekat permukaan medium (Arie Herlambangan, 2002). Pengolahan lanjutan secara aerob pada biofilter dapat mengolah air limbah yang masih memiliki kadar zat organik dan akan diubah menjadi zat-zat yang tidak mencemari lingkungan (Rudi Nugroho, 2010).

Kadar COD maksimal yang telah ditentukan pada baku mutu Peraturan Daerah Provinsi Jawa Tengah Nomor 5 Tahun 2012 yaitu $275 \mathrm{mg} / \mathrm{l}$. Hal tersebut menunjukan bahwa kadar COD pada influent dan effluent tidak melebihi baku mutu, sehingga effluent biofilter aerob menggunakan media botol susu fermentasi telah memenuhi syarat.

Influent biofilter aerob sebelum dilakukan pengolahan sudah memiliki kadar COD dibawah standar baku mutu saat penelitian berlangsung. Biodigester unit 3 mengalami kebocoran sebelum penelitian dilaksanakan, sehingga petugas pengelola segera melakukan perbaikan. Biodigester unit 3 telah dilakukan perbaikan tepat sebelum penelitian dilaksanakan, sehingga pengolahan air limbah tahu pada biodigester tersebut dapat terjadi tanpa adanya hambatan. Bahan pencemar pada air limbah dapat terolah dengan baik, oleh karena itu effluent biodigester unit 3 memiliki kadar COD yang tidak melebihi baku mutu sebelum diolah menggunakan biofilter aerob.

5) Efisiensi penurunan COD

Rerata hasil penghitungan efisiensi biofilter aerob menggunakan media botol susu fermentasi adalah 66,846\%. Menurut Abdullah (2007), instalasi pengolah limbah dikatakan efisien apabila efisiensi pada instalasi tersebut berkisar antara 80-95\%, sehingga efisiensi penurunan COD pada biofilter aerob lebih kecil dari ketentuan efisiensi pada instalasi pengolah limbah. Hal tersebut menunjukkan hipotesis penelitian ini telah ditolak, biofilter aerob media botol susu fermentasi belum efisien dalam menurunkan kadar COD effluent biodigester unit 3 .

Berdasarkan hasil penelitian Nusa Idaman Said (2002), efisiensi penurunan COD pada biofilter setelah dilakukan proses seeding yaitu $70 \%$. Hasil tersebut menunjukkan penurunan COD belum cukup stabil dan masih terlalu rendah. Tahapan selanjutnya setelah dilakukan proses seeding yaitu tahap aklimatisasi. Proses aklimatisasi bertujuan untuk meningkatkan efisiensi biofilter dan menjaga kestabilan efisiensi biofilter. Aklimatisasi dilakukan selama 70-85 hari, kemudian pengolahan air limbah dapat dioperasikan.

Proses aklimatisasi pada penelitian ini tidak dilaksanakan. Hal tersebut menyebabkan mikroorganisme belum mampu mengolah influent secara optimal. Mikroorganisme perlu adaptasi dengan influent, sehingga efisiensi pada penurunan COD dapat meningkat dan kestabilan penurunan COD dapat diperoleh.

Penelitian ini tidak dilakukan pemeriksaan TSS (Total Suspended Solid) dan MLSS (Mixed Liqour Suspended Solids). TSS dan MLSS merupakan parameter kinerja pada proses pengolahan air limbah. Menurut 
Arie Herlambangan (2002), parameter TSS dan MLSS adalah jumlah total dari padatan tersusensi berupa material organik, mineral dan mikroorganisme. Parameter ini sering dilakukan pemeriksaan untuk mengetahui jumlah mikroorganisme pada lumpur yang telah terbentuk setelah proses seeding. Penelitian ini tidak dilakukan pemeriksaan TSS dan MLSS sehingga jumlah mikroorganisme yang telah berkembang biak tidak diketahui sudah cukup untuk mengolah kadar COD pada effluent biodigester unit 3 .

Penelitian ini hanya dilakukan 1 kali dengan luas spesifik media biofilter aerob yaitu $1.719,95 \mathrm{~cm}^{2} /$ liter. Luas spesifik pada media belum mampu untuk menurunkan kadar COD secara efisien, sehingga perlu dilakukan penelitian lanjut dengan menambah luas spesifik media botol susu fermentasi dalam menurunkan kadar COD. Penambahan luas spesifik pada media biofilter aerob dapat dilakukan dengan menambahkan botol susu fermentasi yang telah ditekan secara horizontal, sehingga luas spesifik media botol susu semakin bertambah dan efisiensi penurunan kadar COD dapat mencapai 80-95\%. Menurut Dirjen Bina Upaya Kesehatan (2011), luas permukaan total yang tersedia untuk pertumbuhan bakteri merupakan indikator dari kapasitas biofilter untukenghilangkan polutan. Semakin besar luas permukaan per satuan volume media maka jumlah mikroorganisme yang tumbuh dan menempel pada permukaan media makin banyak sehingga efisiensi pengolahan menjadi lebih besar.

6) Hasil Analisis Perbedaan COD Influent dan Effluent Biofilter Aerob

Hasil analisis statistik tersebut diperoleh nilai signifikan ( $P$ value) sebesar 0,07. Nilai sig tersebut menunjukan bahwa nilai sig $(P$ value $)>$ $\alpha(0,05)$, sehingga tidak ada perbedaan yang signifikan antara hasil pemeriksaan COD sebelum dan sesudah dilakukan pengolahan menggunakan biofilter aerob. Hal ini disebabkan karena kurangnya tahap aklimatisasi sebelum influent diolah menggunakan biofilter aerob, sehingga penurunan kadar COD belum mencapai kondisi stabil. Selain itu, luas permukaan media biofilter aerob yang efisien dalam menurunkan kadar COD belum diketahui, sehingga penurunan COD pada biofilter aerob tidak signifikan.

\section{Kesimpulan dan Saran}

A. Kesimpulan

1) Hasil rata-rata suhu influent biofilter aerob yaitu $26,16^{\circ} \mathrm{C}$, kemudian hasil rata-rata $\mathrm{pH}$ influent biofilter aerob yaitu 6,53.

2) Hasil rata-rata pemeriksaan COD influent biofilter aerob yaitu 97,667 $\mathrm{mg} / \mathrm{l}$.

3) Hasil rata-rata suhu effluent biofilter aerob yaitu $28,16^{\circ} \mathrm{C}$, kemudian hasil rata-rata $\mathrm{pH}$ effluent biofilter aerob yaitu 7,5.

4) Hasil rata-rata pemeriksaan COD effluent biofilter aerob yaitu 30,667 $\mathrm{mg} / \mathrm{l}$.

5) Rata-rata efisiensi penurunan kadar COD pada biofilter aerob yaitu $66,846 \%$.

6) Hasil analisis statistik kadar COD diperoleh nilai signifikan ( $P$ value $)$ sebesar 0,07. Nilai sig tersebut menunjukan bahwa sig $(P$ value $)>\alpha$ $(0,05)$, sehingga tidak ada perbedaan yang signifikan antara hasil pemeriksaan COD influent dan effluent biofilter aerob.

7) Rata-rata kadar COD pada effluent biofilter aerob yaitu 30,667 mg/l. Kadar COD maksimal yang telah ditentukan oleh Peraturan Daerah Provinsi Jawa Tengah Nomor 5 Tahun 2012 yaitu 275 mg/l. Kadar COD effluent biofilter aerob tidak melebihi kadar maksimal pada baku mutu, sehingga kadar COD effluent biofilter telah memenuhi syarat.

B. Saran

1) Petugas Pengelola Biodigester Unit 3 dan Kelompok UKM Tahu Wilayah 3 Desa Kalisari Kecamatan Cilongok

Petugas Pengelola Biodigester Unit 3 bersama Kelompok UKM Tahu Wilayah 3 Desa Kalisari Kecamatan Cilongok diharapkan membuat instalasi pengolahan lanjut air limbah tahu setelah diolah menjadi biogas, salah satunya dengan menggunakan biofilter aerob dengan media botol susu fermentasi untuk mengantisipasi kadar COD yang tinggi pada effluent biodigester unit 3 .

2) Institusi

Dijadikan sebagai referensi perbendaharaan ilmu pengetahuan, kepustakaan bagi Jurusan Kesehatan Lingkungan Purwokerto pada khususnya tentang pengelolaan air 
limbah menggunakan biofilter aerob media botol susu fermentasi.

3) Peneliti Lain

a. Perlu dilakukan penelitian lanjut dengan menambah luas spesifik media botol susu fermentasi dalam menurunkan kadar COD. Penambahan luas spesifik pada media biofilter aerob dapat dilakukan dengan menambahkan botol susu fermentasi yang telah dipres secara horizontal, sehingga luas spesifik media botol susu semakin bertambah dan efisiensi penurunan kadar COD dapat mencapai $80-95 \%$.

b. Perlu dilakukan proses aklimatisasi setelah proses seeding antara 70-85 hari, sehingga efisiensi penurunan COD pada biofilter aerob dapat mencapai $80-95 \%$.

c. Perlu dilakukan penelitian lanjut dengan pemeriksaan parameter kinerja biofilter aerob meliputi kadar Oksigen, pemeriksaan TSS dan konsentrasi MLSS yang berhubungan dengan kinerja penurunan Kadar COD air limbah pada pengoperasian biofilter aerob.

\section{Daftar Pustaka}

Abas Sato. 2015. Pengolahan Limbah Tahu Secara Anaerobik-Aerobik Kontinyu. Surabaya: Institut Teknologi Adhi Tama

Ade Triyasa. 2014. Analisis Kelayakan Lingkungan dan Ekonomi Instalasi Pengolahan Air Limbah Biogas pada Industri Tahu. Surabaya : Jurnal Prosiding Seminar Nasional Kimia. ISBN : 978-602-0951-00-3

Arie Herlambangan, dkk. 2010. Materi Pelatihan Teknologi Pengolahan Limbah Cair. Jakarta : Pusat Teknologi Lingkungan, Deputi Bidang Teknologi Pengelolaan Sumberdaya Alam. Badan Pengkajian dan Penerapan Teknologi

Arif Sumantri dan Muhammad Reza Cordova. 2011. Dampak Limbah Domestik Perumahan Skala Kecil terhadap Kualitas Air Ekosistem Penerimanya dan Dampaknya Terhadap Kesehatan Masyarakat. Jakarta : Universitas Islam Negeri Syarif Hidayatullah. JPSL Vol. (1)
Badan Pengkajian dan Penerapan Teknologi. 2002. Contoh Perencanaan dan Pembangunan IPAL Domestik. Jakarta: Pusat Teknologi Lingkungan, Deputi Bidang Teknologi Pengelolaan Sumberdaya Alam. Badan Pengkajian dan Penerapan Teknologi

2002. Pengolahan Limbah Industri Tahu Tempe. Jakarta: Pusat Teknologi Lingkungan, Deputi Bidang Teknologi Pengelolaan Sumberdaya Alam

Betty Sri Laksmi Jenie. 1990. Penanganan Limbah Industri Pangan. Bogor: PAU Pangan dan Gizi IPB

Clifton Potter, dkk. 1994. Limbah Cair Berbagai Industri di Indonesia. Canada: Dalhousie University

Danang Biyatmoko. 2012. Identifikasi Keragaman Jenis Bakteri pada Proses Pengolahan Limbah Cair Industri Minuman dengan Lumpur Aktif Limbah Tahu. Banjarmasin : Jurnal EnviroScienteae Nomor 8:89-101

Denise Polit dan Bernadette Hungler. 1999. Principles and Methods. Amerika Serikat : Lippicott

Direktorat Bina Pelayanan Penunjang Medik dan Sarana Kesehatan. 2011. Pedoman Teknis Instalasi Pengolahan Air Limbah dengan Sistem Biofilter Anaerob dan Aerob. Jakarta : Kementerian Kesehatan RI

Doni Harisuseno, dkk. 2012. Studi Perencanaan Instalasi Pengolahan Air Limbah (IPAL) Pabrik Tahu Fit Malang dengan Digester Anaerobik dan Biofilter Anaerobik-Aerobik. Malang : Universitas Brawijaya

Eko Purwaningsih. 2007. Cara Pembuatan Tahu dan Manfaat Kedelai. Bekasi : Ganeca Exact

Fardiaz, Srikandi. 1992. Polusi Air dan Udara. Yogyakarta: Penerbit Kanisius

Fatah Sulaiman.2016. Analisis Kinerja Biofilter Media Kerikil dan Batu Apung Untuk Pengolahan Limbah Cair Industri Tahu. Serang: Universitas Sultan Ageng Tirtayasa 
Ginanjar. 2013. Desa Kalisari Targetkan Seluruh Limbah Tahu Jadi Biogasari. http://www.greeners.co/berita/desakalistargetkan-seluruh-limbah-tahujadi-biogasari/. Diposting pada 28 Maret 2013

Hadi Iswanto dan Kristanto. 2007. Membuat Tahu \& Tempe. Jakarta : Redaksi Agromedia

Heru Dwi Wahjono, dkk. 2002. Teknologi Pengolahan Air limbah Industri. Jakarta: Pusat Pengkajian dan Penerapan Teknologi Lingkungan, Deputi Bidang Teknologi Informasi, Energi, Material dan Lingkungan, Badan Pengkajian dan Penerapan Teknologi

Indonesian Public Health. 2015. Pengertian COD, BOD dan TSS pada Air Limbah. http://www.indonesian-

publichealth.com/pengertian-bod-codtss-pada-air-limbah. Diakses pada 23 September 2017

Kementerian Lingkungan Hidup. 2014. Peraturan Menteri Lingkungan Hidup Nomor 5 Tahun 2014 tentang Baku Mutu Air Limbah. Jakarta : Sekjen RI

Larry Benefield dan Clifford W. Randall. 1978. Biological Process Design for Wastewater Treatment. Amerika: United States of America

Lidya Rahma Shaffitri. 2011. Internalsasi Biaya Ekspternal Pengolahan Limbah Tahu. Bogor : Institut Pertanian Bogor

Mahmud Hasan. 2010. Potensi dari Air limbah Industri Tahu Biogas, e-library.uniskakediri.ac.id/downloads/biogas3616ed.pdf. Diakses pada tanggal 9 Maret 2017

Mohammad Arief. 2016. Pengolahan Limbah Industri. Yogyakarta : UEU University Press

Muhammad Solichin. 2012. Pengelolaan Limbah Cair Proses Biofilm Tercelup (Submerged Biofilter). Malang : Universitas Brawijaya

Masfufahtut Thohuroh. 2015. Studi Perencanaan Instalasi Pengolahan Air Limbah (IPAL) Pabrik Tahu "3 Saudara” Malang dengan Kombinasi
Biofilter Anaerobik - Aerobik. Malang: Universitas Brawijaya

Mutiara Nugraeheni. 2008. Inotek Kecap Ampas Tahu. Yogyakarta : Universitas Negeri Yogyakarta

Novan Bagas Sayoga. 2017. Peningkatan Kualitas Effluent Limbah Cair Tahu dengan Menggunakan Sistem Wastewater Double Treatment (AerobAnaerob). Malang: Universitas Brawijaya

Nusa Idaman Said. 1999. Teknologi Pengolahan Air Limbah Tahu-Tempe dengan Proses Biofilter Anaerob dan Aerob. Jakarta : Badan Pengkajian dan Penerapan Teknologi

Okta Lumakeki. 2013. Fitoremediasi Limbah Tahu. Universitas Kristen Indonesia Tomohon,

https://www.scribd.com/doc/15383990 8/Jurnal-Fitoremediasi-Limbah-TahuLengkap-Plagiarism. Diakses pada 9 maret 2017

Pemerintah Provinsi Jawa Tengah. 2012. Peraturan Daerah Provinsi Jawa Tengah Nomor 5 Tahun 2012 tentang Baku Mutu Air Limbah. Semarang : Sekda Provinsi Jateng

Ridho Hasan. 2016. Dampak COD terhadap Manusia dan Lingkungan. https://www.scribd.com/doc/29815319 6/Dampak-COD-Terhadap-ManusiaDan-Lingkungan. Diakses pada 21 Desember 2017

Shabrina Arika Zahra. 2016. Penurunan Konsentrasi BOD dan COD pada Limbah Cair Tahu dengan Teknologi Kolam (Pond) - Biofilm Menggunakan Media Biofilter Jaring Ikan Dan Bioball. Semarang: Universitas Diponegoro

Siregar, Sakti Azhar. 2005. Instalasi Pengolahan Air Limbah. Yogyakarta: Penerbit Kanisius

Soeparman dan Suparmin. 2002. Pembuangan Tinja dan Air limbah. Jakarta : Penerbit Buku Kedokteran EGC

Sri Sumarsih. 2013. Mikrobiologi Dasar. Yogyakarta : Fakultas Pertanian UPN Veteran Yogyakarta 
Sugiharto. 1987. Dasar-Dasar Pengelolaan Air Limbah. Jakarta: Universitas Indonesia

Tri Cahyono. 2018. Panduan Penulisan Skripsi. Purwokerto: Jurusan Kesehatan Lingkungan Purwokerto

Triyanto. 2012. Perencanaan Eksperimen. https://triyantounsoed.wordpress.com/2 012/01/15/perencanaan-eksperimen/. Diakses pada 24 November 2017

Yaniar Nuraini. 2012. Penurunan Senyawa Organik Limbah Cair Industri Tahu dengan Proses Biofilter Aerob. Surabaya: Universitas Pembangunan Nasional "Veteran" 